\title{
PENGARUH PROFITABILITAS TERHADAP NILAI PERUSAHAAN DENGAN STRUKTUR MODAL SEBAGAI VARIABEL INTERVENING PADA PERUSAHAAN PEMBIAYAAN YANG TERDAFTAR DI BEI
}

\author{
Ni Ketut Sulastri ${ }^{1}$ Ni Ketut Surasni ${ }^{2}$ Hermanto $^{3}$ \\ ${ }^{1}$ Fakultas Ekonomi dan Bisnis Universitas Mataram, lastri.stahn@gmail.com \\ ${ }^{2}$ Fakultas Ekonomi dan Bisnis Universitas Mataram, surasni12@gmail.com \\ ${ }^{3}$ Fakultas Ekonomi dan Bisnis Universitas Mataram, lastri.stahn@gmail.com
}

\begin{abstract}
ABSTRAK
Penelitian ini bertujuan untuk menganalisis pengaruh profitabilitas terhadap struktur modal, pengaruh struktur modal terhadap nilai perusahaan, pengaruh profitabilitas terhadap nilai perusahaan dan menganalisis pengaruh profitabilitas terhadap nilai perusahaan melalui struktur modal pada perusahaan pembiayaan di BEI. Teknik analisis data dalam penelitian ini adalah Path Analisis dan alat analisis yang digunakan adalah IBM SPSS 23. Hasil penelitian menunjukkan bahwa (1) profitabilitas berpengaruh positif dan tidak signifikan terhadap struktur modal (2) struktur modal berpengaruh positif dan tidak signifikan terhadap nilai perusahaan (3) profitabilitas berpengaruh positif dan sinifikan terhadap nilai perusahaan (4) struktur modal tidak mampu memediasi pengaruh profitabilitas terhadap nilai perusahaan.
\end{abstract}

Kata Kunci: Perusahaan Pembiayaan, Profitabilitas, Struktur Modal dan Nilai Perusahaan

\begin{abstract}
This study aimed to analyze the effect of profitability on capital structure, the influence of capital structure on firm value, the effect of profitability on firm value and analyze the effect of profitability on firm value through capital structure on finance companies on the IDX. Data analysis technique in this study is Path Analysis and tools of analysis used are IBM SPSS 23. The results of the study show that (1) profitability has a positive and not significant effect on capital structure (2) capital structure has a positive and not significant effect on firm value (3 ) profitability has a positive and significant effect on firm value (4) capital structure is not able to mediate the effect of profitability on firm value.
\end{abstract}

Keywords: Finance Company, Profitability, Capital Structure and Firm Value

\section{PENDAHULUAN}

Perusahaan didirikan dengan tujuan tertentu yang ingin dicapai pemilik perusahaan, tujuan tersebut dapat berupa tujuan jangka panjang maupun tujuan jangka pendek. Tujuan jangka pendek berupa pencapaian laba secara maksimal dengan menggunakan sumber daya yang ada sementara tujuan jangka panjang yaitu memaksimalkan nilai perusahaan. Nilai perusahaan merupakan persepsi investor terhadap tingkat keberhasilan perusahaan yang sering dikaitkan dengan harga saham. Adapun faktor-faktor yang mempengaruhi nilai perusahaan yaitu antara lain ukuran perusahaan, profitabililtas, pertumbuhan laba, likuiditas, dan inflasi. 
Profitabilitas suatu perusahaan diukur dengan kesuksesan perusahaan dan kemampuan menggunakan aktivanya secara produktif, dengan demikian profitabilitas suatu perusahaan dapat diketahui dengan memperbandingkan antara laba yang diperoleh dalam suatu periode dengan jumlah aktiva atau jumlah modal perusahaan. Sesuai dengan signalling theory peningkatan profitabilitas akan ditangkap sebagai sinyal positif yang dapat meningkatkan kepercayaan untuk menarik modal dari para investor. Profitabilitas menjadi salah satu cerminan perusahaan dihadapan investor dan publik akan prospek perusahaan dimasa depan. Semakin tinggi nilai profitabilitas maka semakin tinggi pula nilai perusahaan dan menunjukkan kemampuan perusahaan secara efektif menggunakan sumber daya yang dimiliki. Teori lainnya yaitu trade off theory dimana perusahaan dengan tingkat profitabilitas yang tinggi akan berusaha mengurangi pajaknya dengan cara meningkatkan rasio utangnya.

Keputusan struktur modal dalam perusahaan merupakan hal yang penting. Pentingnya struktur modal karena adanya pilihan kebutuhan antara memaksimalkan return (meminimalkan biaya modal) dengan kemampuan perusahaan dalam menghadapi lingkungan bisnis yang kompetitif. Sesuai dengan teori struktur modal apabila posisi struktur modal berada di atas target struktur modal optimalnya maka setiap pertambahan hutang akan menurunkan nilai perusahaan. Oleh karena itu penelitian ini bertujuan untuk mengetahui pengaruh profitabilitas (ROE) terhadap struktur modal (DER), pengaruh struktur modal (DER) terhadap nilai perusahaan (PBV), pengaruh profitabilitas (ROE) terhadap nilai perusahaan (PBV) dan pengaruh profitabilitas (ROE) terhadap nilai perusahaan (PBV) melalui struktur modal (DER).

\section{TINJAUAN LITERATUR}

Pengaruh Profitabilitas terhadap struktur modal diteliti oleh beberapa orang yang tertuang dalam beberapa jurnal penelitian yaitu antara lain oleh Ananda \& Putra (2016) yang menyimpulkan bahwa Profitabilitas berpengaruh positif dan signifikan terhadap struktur modal yang artinya bahwa profitabilitas yang tinggi akan meningkatkan struktur modal perusahaan. Hal ini terjadi dikarenakan adanya penghematan pajak yang didapatkan perusahaan dengan penggunaan hutang. Sesuai dengan teori trade off, bunga yang dibayarkan sebagai beban pengurang pajak membuat utang lebih murah daripada saham biasa atau preferen. Begitu pula halnya dengan hasil penelitian yang dilakukan oleh Hermuningsih (2012) bahwa profitabilitas berpengaruh positif dan signifikan terhadap struktur modal. Hasil ini menunjukkan bahwa perusahaan-perusahaan besar yang profitable cenderung menggunakan hutang untuk operasi perusahaannnya, sebaliknya menurut Nurul Azmi (2018) variabel profitabilitas berpengaruh negatif terhadap struktur modal. Pengaruh profitabilitas terhadap nilai perusahaan menurut penelitian yang dilakukan oleh Rahayu \& Sari (2016) bahwa profitabilitas yang diproksikan dengan return on equity tidak berpengaruh terhadap nilai perusahaan, sedangkan menurut Pasaribu \& dkk (2016) dalam jurnal yang tulis menyimpulkan bahwa ROE ternyata berpengaruh posititif signifikan terhadap nilai perusahaan. Berbeda halnya menurut Nurul Azmi dkk (2018) bahwa variabel profitabilitas berpengaruh negatif dan tidak signifikan terhadap nilai perusahaan. 
Menurut Ananda \& Putra (2016) bahwa profitabilitas berpengaruh terhadap nilai perusahaan melalui struktur modal, artinya bahwa perusahaan dengan profit yang tinggi cenderung menggunakan hutang dalam struktur modal. Hal ini terjadi dikarenakan adanya penghematan pajak yang didapatkan perusahaan dengan penggunaan hutang. Penggunaan hutang yang melebihi titik optimalnya telah mendorong penurunan nilai perusahaan. Perkiraan tingkat pengembalian yang tinggi diakibatkan oleh penggunaan hutang yang lebih besar akan meningkatkan harga saham tetapi risiko yang tinggi terkait penggunaan hutang dapat menurunkan harga saham. Ketika risiko usaha lebih besar daripada tingkat pengembalian, maka nilai perusahaan akan menurun. Sedangkan menurut Nurul Azmi dkk (2018) bahwa variabel struktur modal sebagai variabel intervening tidak dapat memediasi hubungan antara profitabilitas terhadap nilai perusahaan.

\section{METODE PENELITIAN}

Jenis penelitian ini adalah penelitian asosiatif kausal. Tujuan dari penelitian asosiatif kausal untuk mengetahui ada dan tidaknya pengaruh atau hubungan antara variabel bebas terhadap variabel terikat. Metode pengumpulan data yang digunakan di dalam penelitian ini adalah dokumentasi yaitu teknik pengumpulan data dari dokumentasi laporan keuangan yang dipublikasi oleh perusahaan pembiayaan yang terdaftar di BEI dalam situs resmi BEI. Populasi dalam penelitian ini adalah 17 perusahaan pembiayaan yang tercatat di BEI, sedangkan pengambilan sampel dalam penelitian ini dilakukan dengan menggunakan metode purposive sampling. Dari 17 populasi tersebut hanya terdapat 11 sampel perusahaan yang memenuhi kriteria. Penelitian ini menggunakan jenis data kuantitatif, yaitu data yang berbentuk angka-angka. Data kuantitatif yang digunakan dalam penelitian ini antara lain yaitu laporan keuangan, rasio ROE, PBV dan DER yang terdapat pada perusahaan pembiayaan yang terdaftar di BEI. Jenis data dalam penelitian ini menggunakan menggunakan jenis data sekunder yaitu data yang diperoleh secara tidak langsung dalam bentuk sudah jadi, yang telah dikumpulkan dan dicatat oleh pihak lain melalui www.idx.co.id. Data yang dikumpulkan tersebut berupa laporan keuangan perusahaan selama periode 2014 sampai 2017. Data sekunder dalam penelitian ini berupa profitabilitas (ROE), Nilai Perusahaan (PBV), serta Struktur Modal (DER).

\section{HASIL PENELITIAN DAN PEMBAHASAN}

\section{HASIL PENELITIAN}

\section{Statistik Deskriptif}

Tabel 1. Hasil Statistik Deskriptif

\begin{tabular}{|l|r|r|r|r|r|r|}
\hline & N & \multicolumn{1}{|c|}{ Range } & Minimum & Maximum & \multicolumn{1}{c|}{ Mean } & $\begin{array}{c}\text { Standar } \\
\text { Deviasi }\end{array}$ \\
\hline ROE & 44 & .24 & .01 & .25 & .1020 & .05961 \\
\hline DER & 44 & 7.22 & .01 & 7.23 & 2.5239 & 2.07016 \\
\hline PBV & 44 & 8.87 & .26 & 9.13 & 1.3866 & 1.49995 \\
\hline $\begin{array}{l}\text { Valid N } \\
\text { (listwise) }\end{array}$ & 44 & & & & & \\
\hline
\end{tabular}

Sumber : data yang diolah dengan SPSS

Dari hasil analisis statistik deskripstif terlihat bahwa rata-rata ROE relatif kecil bila dibandingkan dengan rata-rata DER dan PBV. Hal ini mengindikasikan bahwa profitabilitas perusahaan sampel cukup kecil dikarenakan terdapat beberapa perusahaan yang mengalami kerugian cukup tinggi sehingga mempengaruhi rata-rata profitabilitas 
secara umum.

\section{Uji Normalitas}

Tabel 2. Hasil Uji Normalitas $(\mathrm{N}=44)$

\begin{tabular}{|l|l|r|}
\hline \multicolumn{2}{|c|}{ One-Sample Kolmogorov-Smirnov Test } \\
\hline N & \multicolumn{1}{|c|}{ Unstandardized Residual } \\
\hline \multirow{2}{*}{ Normal Parameters ${ }^{\mathrm{a}, \mathrm{b}}$} & Mean & .0000000 \\
\cline { 2 - 4 } & Std. Deviation & 1.42426780 \\
\hline \multirow{2}{*}{ Most Extreme Differences } & Absolute & .201 \\
\cline { 2 - 4 } & Positive & .201 \\
\cline { 2 - 3 } & Negative & -.179 \\
\hline Test Statistic & .201 \\
\hline Asymp. Sig. (2-tailed) & $.000^{\mathrm{c}}$ \\
\hline Sumber : data yang diolah dengan SPSS & \\
\hline
\end{tabular}

Hasil uji normalitas menunjukkan bahwa nilai signifikansi sebesar 0,000 yang mana nilai tersebut $<0,05$ artinya bahwa data tersebut dinilai tidak normal, sehingga perlu dilakukan penormalan data melalui screening yaitu mendeteksi adanya data outlier.

Tabel 3. Hasil Uji Normalitas $(\mathrm{N}=39)$

\begin{tabular}{|c|c|c|}
\hline \multicolumn{2}{|c|}{$\begin{array}{c}\text { One-Sample Kolmogorov-Smirnov Test } \\
\text { (Setelah dihilangkan Outlier) }\end{array}$} \\
\hline \multicolumn{2}{|c|}{$\mathrm{N}$} & Unstandardized Residual \\
\hline \multicolumn{2}{|c|}{} & 39 \\
\hline Normal Parameters ${ }^{\mathrm{a}, \mathrm{b}}$ & Mean & .0000000 \\
\cline { 2 - 3 } & Std. Deviation & .43641314 \\
\hline Most Extreme Differences & Absolute & .116 \\
\cline { 2 - 3 } & Positive & .116 \\
\cline { 2 - 3 } & Negative & -.096 \\
\hline \multicolumn{2}{|c|}{ Test Statistic } & .116 \\
\hline \multicolumn{2}{|c|}{ Asymp. Sig. (2-tailed) } \\
\hline Sumber : data diolah dengan SPSS \\
\hline
\end{tabular}

Kembali dilakukannya uji normalitas setelah menghilangkan data outlier dengan menggunakan uji One-Sample Kolmogorov-Smirnov Test terlihat bahwa nilai signifikansi menunjukkan nilai 0,20 diatas 0,05 . Hal ini menunjukkan bahwa nilai residual terdistribusi secara normal atau memenuhi asumsi dasar normalitas dengan $\mathrm{n}$ berjumlah 39 .

\section{Uji Asumsi Klasik Uji Autokorelasi}

Tabel 4. Hasil Uji Autokorelasi

\begin{tabular}{|c|c|c|c|c|c|}
\hline \multicolumn{7}{|c|}{ Model Summary $^{\mathbf{b}}$} \\
\hline Model & $\mathrm{R}$ & R Square & $\begin{array}{c}\text { Adjusted R } \\
\text { Square }\end{array}$ & $\begin{array}{c}\text { Std. Error of the } \\
\text { Estimate }\end{array}$ & Durbin-Watson \\
\hline 1 & $.405^{\mathrm{a}}$ & .164 & .118 & .44837 & 1.266 \\
\hline \multicolumn{4}{|l}{ a. Predictors: (Constant), DER, ROE } \\
\multicolumn{4}{l}{ b. Dependent Variable: PBV }
\end{tabular}

Sumber data : data yang diolah dengan SPSS 
Hasil analisis menunjukkan nilai durbin watson dengan 2 variabel independen dan 39 sampel terpilih karena adanya outlier maka diperoleh nilai du sebesar 1,5969 dan dl sebesar 1,3821. Nilai autokorelasi $4-\mathrm{du} \leq \mathrm{d} \leq 4-\mathrm{dl}$ maka $4-1,5969 \leq 1,266 \leq 4-$ 1,3821 , hasil yang diperoleh menjadi $2,4031 \leq 1,266 \leq 2,734$. Oleh karena nilai $\mathrm{dw} 1,266$ lebih kecil dari batas bawah $\mathrm{dl}=1,3821$ maka dapat disimpulkan bahwa tidak ada autokorelasi positif.

\section{Uji Heterokedastisitas}

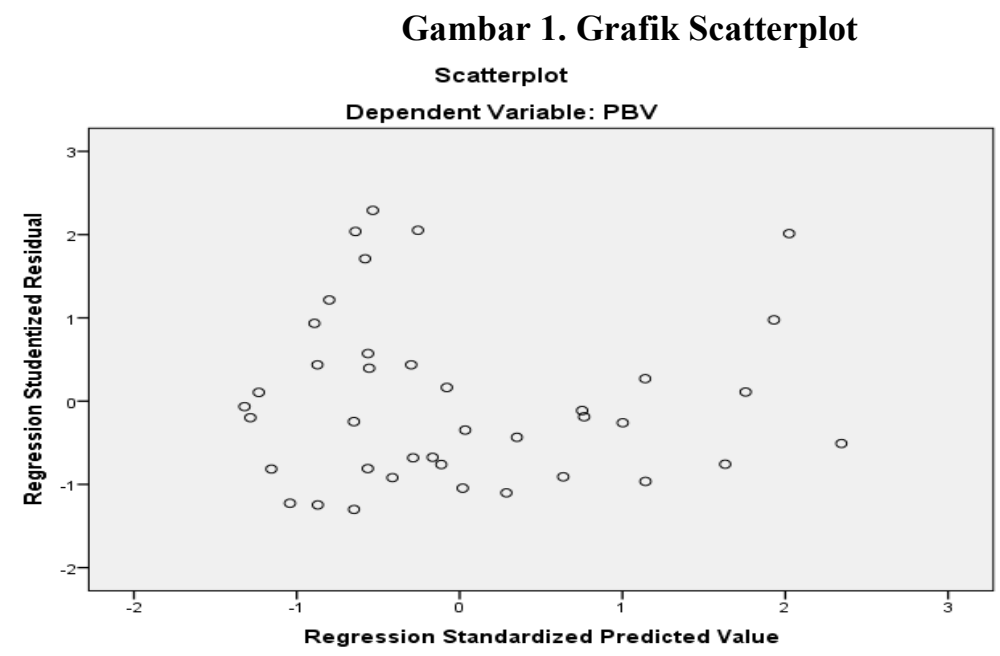

Sumber data : data yang diolah dengan SPSS

Hasil analisis menunjukkan titik-titik menyebar secara acak baik diatas maupun dibawah angka 0 pada sumbu Y, sehingga dapat disimpulkan bahwa tidak ada heterokedastisitas pada model regresi sehingga model regresi layak dipakai untuk memprediksi nilai perusahaan berdasarkan masukan variabel independen profitabilitas dan struktur modal.

\section{Uji Koefisien Determinasi $\left(\mathbf{R}^{2}\right)$}

Tabel 5. Hasil Analisis Koefisien Determinasi Model I

Model Summary

\begin{tabular}{|c|c|c|c|c|}
\hline Model & R & R Square & Adjusted R Square & Std. Error of the Estimate \\
\hline 1 & $.384^{\mathrm{a}}$ & .148 & .125 & .44662 \\
\hline
\end{tabular}

Predictors: (Constant), ROE

Sumber data : data yang diolah dengan SPSS

Tabel 6. Hasil Analisis Koefisien Determinasi Model II

Model Summary ${ }^{b}$

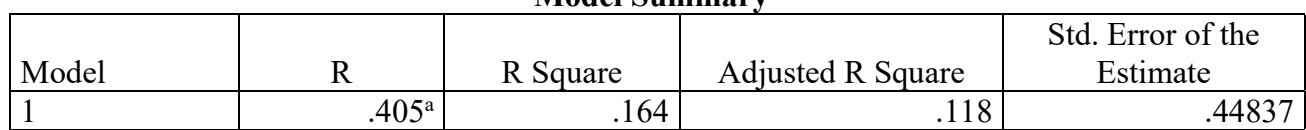

a. Predictors: (Constant), DER, ROE

b. Dependent Variable: PBV

Sumber data : data yang diolah dengan SPSS

$\mathrm{R}^{2}$ model

$$
\begin{aligned}
& =1-\left(1-\mathrm{R}^{2} 1\right)\left(1-\mathrm{R}^{2} 2\right) \\
& =1-(1-0,148)(1-0,164) \\
& =1-(0,852)(0,836) \\
& =1-0,712272 \\
& =0,287728 \text { atau } 28,77
\end{aligned}
$$


Hasil perhitungan ketepatan model sebesar $28,77 \%$ hal ini menunjukkan bahwa kontribusi model untuk menjelaskan hubungan struktural dari ketiga variabel yang diteliti sebesar $28,77 \%$ dan sisanya sebesar $71,23 \%$ dipengaruhi oleh variabel lain yang tidak terdapat dalam model ini.

\section{Uji Statistik t}

Tabel 7. Hasil Uji Statistik t

Coefficients $^{\mathbf{a}}$

\begin{tabular}{|c|c|c|c|c|c|c|}
\hline \multirow{2}{*}{\multicolumn{2}{|c|}{ Model }} & \multicolumn{2}{|c|}{ Unstandardized Coefficients } & \multirow{2}{*}{$\begin{array}{c}\text { Standardized } \\
\text { Coefficients } \\
\text { Beta }\end{array}$} & \multirow[b]{2}{*}{$\mathrm{t}$} & \multirow[b]{2}{*}{ Sig. } \\
\hline & & $\mathrm{B}$ & Std. Error & & & \\
\hline \multirow[t]{3}{*}{1} & (Constant) & .612 & .166 & & 3.683 & .001 \\
\hline & ROE & 2.905 & 1.193 & .373 & 2.435 & .020 \\
\hline & DER & .030 & .035 & .129 & .844 & .404 \\
\hline
\end{tabular}

Dependent Variabel : PBV

Sumber : data diolah dengan SPSS

Menunjukkan pengaruh ROE dan DER terhadap PBV dengan nilai standar coefficients sebesar 0,373 dimana ROE nilai thitung $=2,435$ dan tabel 2,028 maka bisa dituliskan thitung $2,435>$ tabel 2.028 dengan tingkat signifikansi sebesar 0,020 yakni dibawah 0,05 yang berarti bahwa variabel ROE berpengaruh positif dan signifikan terhadap PBV. Sedangkan pengaruh DER terhadap PBV dengan nilai standar coefficients sebesar 0,129 dimana DER nilai thitung $=0,844$ dan $t_{\text {tabel }} 2,028$ maka bisa dituliskan thitung $0,844<t_{\text {tabel }} 2,028$ dengan tingkat signifikansi sebesar 0,404 yakni diatas 0,05 yang berarti bahwa DER berpengaruh positif dan tidak signifikan terhadap PBV.

\section{Analisa Jalur}

Mediasi sederhana ini terjadi jika dipenuhi asumsi (Ghozali, 2016) : tidak ada kesalahan pengukuran pada variabel struktur modal dan variabel nilai perusahaan tidak mempengaruhi struktur modal.

$$
\begin{aligned}
& Y=\alpha 1+c X \\
& M=\alpha 2+a X \\
& Y=\alpha 3+c^{\prime} X+b M
\end{aligned}
$$

Variabel $\mathrm{M}$ disebut mediator atau intervening jika persamaan (1) X secara signifikan mempengaruhi $\mathrm{Y}$ (atau $\mathrm{c} \neq 0$ ), persamaan (2) $\mathrm{X}$ secara siginifikan mempengaruhi $\mathrm{M}$ (atau $\alpha \neq 0$ ) mempengaruhi $\mathrm{Y}$ dengan persamaan (3) $\mathrm{X}$ secara signifikan mempengaruhi $\mathrm{Y}$ dengan mengkontrol $X($ atau $b \neq 0$ ). Jika pengaruh $X$ terhadap $Y$ signifikan dan menurun menjadi nol dengan memasukkan variabel $\mathrm{M}$, maka terjadi mediasi sempurna (perfect mediation). Namun demikian jika pengaruh $\mathrm{X}$ terhadap $\mathrm{Y}$ signifikan dan menurun tidak sama dengan nol dengan memasukkan variabel $\mathrm{M}$ maka terjadi mediasi parsial (partial mediation). Mediasi sederhana ini terjadi jika dipenuhi asumsi 1) tidak ada kesalahan pengukuran (measurement error) pada variabel $\mathrm{M}$ dan 2) variabel Y tidak mempengaruhi M. 
Tabel 8. Hasil Pengujian Regresi Persamaan I

Coefficients ${ }^{\mathrm{a}}$

\begin{tabular}{|c|c|c|c|c|c|c|}
\hline \multirow{2}{*}{\multicolumn{2}{|c|}{ Model }} & \multicolumn{2}{|c|}{ Unstandardized Coefficients } & $\begin{array}{l}\text { Standardized } \\
\text { Coefficients }\end{array}$ & \multirow[b]{2}{*}{$\mathrm{t}$} & \multirow[b]{2}{*}{ Sig. } \\
\hline & & $\mathrm{B}$ & Std. Error & Beta & & \\
\hline \multirow[t]{2}{*}{1} & (Constant) & .684 & .142 & & 4.834 & .000 \\
\hline & ROE & 2.997 & 1.183 & .384 & 2.533 & .016 \\
\hline
\end{tabular}

Dependent Variable: PBV

Sumber : data diolah dengan SPSS

Bahwa nilai Standardized Beta ROE pada persamaan (I) sebesar 0,384 dan signifikan pada $0,016(>0,05)$ yang berarti ROE secara signifikan mempengaruhi PBV. Nilai 0,384 merupakan nilai path atau jalur $\mathrm{p} 1$.

Tabel 9. Hasil Pengujian Regresi Persamaan II

\begin{tabular}{|cc|c|c|c|c|c|}
\hline \multirow{2}{*}{ Model } & \multicolumn{2}{|c|}{$\begin{array}{c}\text { Unstandardized } \\
\text { Coefficients }\end{array}$} & \multicolumn{1}{|c|}{$\begin{array}{c}\text { Standardized } \\
\text { Coefficients }\end{array}$} & & \\
\cline { 2 - 4 } & $\mathrm{B}$ & Std. Error & Beta & $\mathrm{t}$ & Sig. \\
\hline \multirow{2}{*}{1} & (Constant) & 2.433 & .661 & & 3.681 & .001 \\
& ROE & 3.083 & 5.523 & .091 & .558 & .580 \\
\hline
\end{tabular}

Dependent Variable: DER

Sumber : data diolah dengan SPSS

Menunjukkan bahwa nilai Standardized Beta ROE pada persamaan II sebesar 0,091 dan tidak signifikan pada nilai signifikansi $0,580(>0,05)$ yang berarti ROE tidak signifikan mempengaruhi DER. Nilai 0,091 merupakan nilai path atau jalur p2.

Tabel 10. Hasil pengujian Regresi Persamaan III

\begin{tabular}{|c|c|c|c|c|c|c|}
\hline \multicolumn{7}{|c|}{ Coefficients $^{\mathbf{a}}$} \\
\hline \multirow{2}{*}{\multicolumn{2}{|c|}{ Model }} & \multicolumn{2}{|c|}{ Unstandardized Coefficients } & $\begin{array}{c}\text { Standardized } \\
\text { Coefficients }\end{array}$ & \multirow[b]{2}{*}{$\mathrm{T}$} & \multirow[b]{2}{*}{ Sig. } \\
\hline & & $\mathrm{B}$ & Std. Error & Beta & & \\
\hline 1 & (Constant) & .612 & .166 & & 3.683 & .001 \\
\hline & ROE & 2.905 & 1.193 & .373 & 2.435 & .020 \\
\hline & DER & .030 & .035 & .129 & .844 & .404 \\
\hline
\end{tabular}

a. Dependent Variable: PBV

Nilai Standardized Beta DER sebesar 0,129 merupakan nilai jalur p3. Nilai signifikansi sebesar 0,404 (>0,05). Artinya bahwa DER pada persamaan III sebesar 0,129 berpengaruh positif dan tidak signifikan pada 0,404 $(>0,05)$. Nilai e berfungsi untuk menjelaskan jumlah variance yang tidak dapat di jelaskan (Unexplained variance) oleh variabel itu. Besarnya nilai dari e dapat dihitung dengan $\mathrm{e}=\sqrt{ } 1-R^{2}$, sehingga besarnya nilai e1 $=\sqrt{ }(1-0,148)=0,923038$ dan besarnya e $2=\sqrt{ }(1-0,164)=0,914330$ 


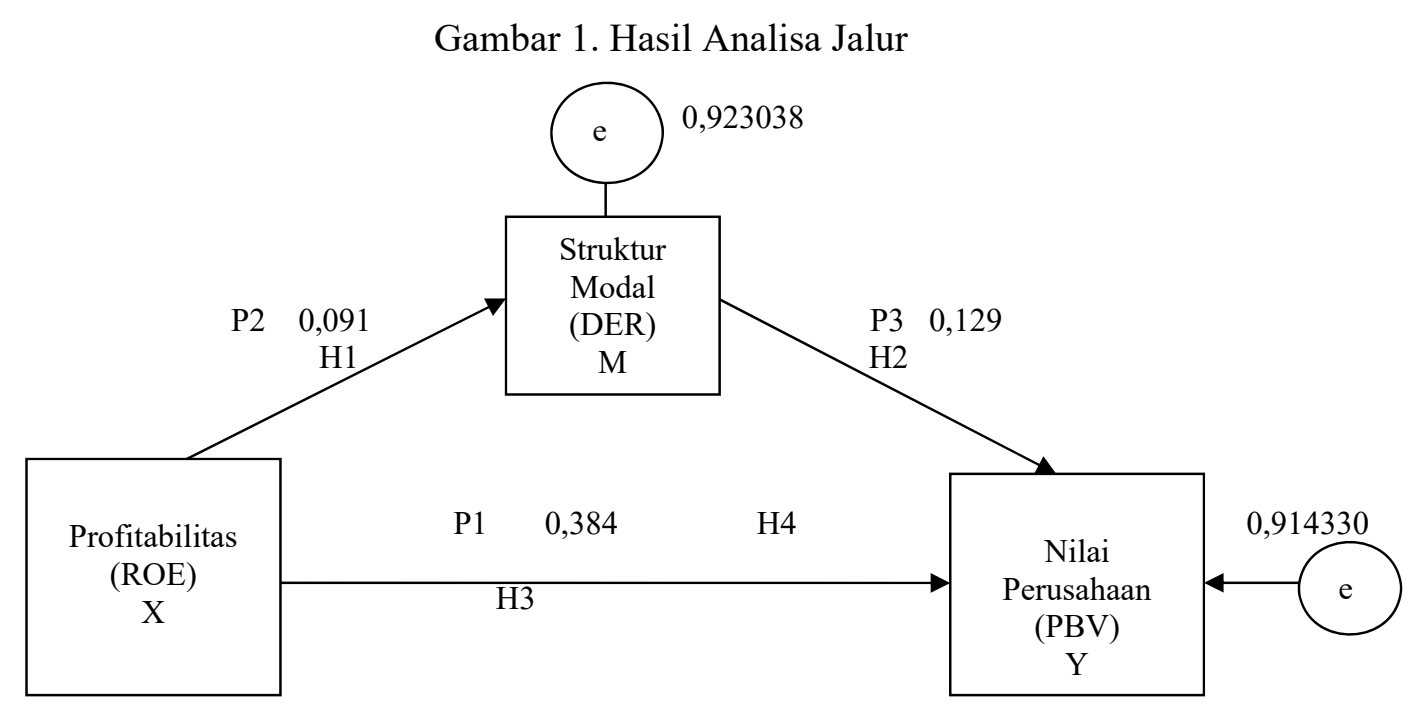

\section{Pengaruh Langsung, tidak langsung dan Total Pengaruh}

Besarnya pengaruh langsung ROE terhadap PBV adalah 0,384 dengan pengaruh yang signifikan, sedangkan untuk melihat pengaruh tidak langsung profitabilitas terhadap nilai perusahaan yang dimediasi oleh struktur modal dilakukan dengan cara mengalikan koefisien tidak langsungnya, sedangkan total pengaruh didapat dari penjumlahan pengaruh langsung dan pengaruh tidak langsung.

Pengaruh tidak langsung $\quad=\mathrm{PY} 2 \mathrm{X} 1 \times \mathrm{PY} 2 \mathrm{X} 2$

$=0,091 \times 0,129$

$=0,011739$

Total pengaruh $\quad=$ Pengaruh langsung + pengaruh tidak langsung

$=0,384+0,011739$

$=0,395739$

Berdasarkan perhitungan diatas terlihat bahwa pengaruh tidak langsung sebesar 0,011739 yang artinya pengaruh profitabilitas terhadap nilai perusahaan melalui struktur modal sebesar 0,011739 . Pengaruh mediasi yang ditunjukkan melalui perkalian koefisien yang ditunjukkan dengan nilai standardized beta $(\mathrm{p} 2 \times \mathrm{p} 3)=(0,091 \times 0,129)=0,011739$ jadi pengaruh mediasi sebesar 0,011739 . Total pengaruh profitabilitas terhadap nilai perusahaan dengan dimediasi struktur modal sebesar 0,395739 . Nilai yang ditunjukkan dari pengaruh mediasi tersebut tidak mencerminkan tingkat signifikansi.

Tabel 11. Hasil Pengujian Hipotesis

\begin{tabular}{|l|l|c|c|c|c|c|c|}
\hline \multirow{2}{*}{$\begin{array}{l}\text { Variabel } \\
\text { Eksogen }\end{array}$} & \multirow{2}{*}{$\begin{array}{l}\text { Variabel } \\
\text { Endogen }\end{array}$} & \multicolumn{2}{|c|}{$\begin{array}{c}\text { Unstandadized } \\
\text { Coefficients }\end{array}$} & $\begin{array}{c}\text { Standardized } \\
\text { Coefficients } \\
\text { Beta }\end{array}$ & $\mathbf{T}$ & Sig & Ket \\
\cline { 3 - 7 } & DER & 3,083 & 5,523 & 0,091 & 0,558 & 0,580 & $\begin{array}{l}\text { Positif tidak } \\
\text { signifikan }\end{array}$ \\
\hline ROE & PBV & 0,030 & 0,035 & 0,129 & 0,844 & 0,404 & $\begin{array}{l}\text { Positif tidak } \\
\text { signifikan }\end{array}$ \\
\hline ROE & PBV & 2,997 & 1,183 & 0,384 & 2,533 & 0,016 & $\begin{array}{l}\text { Positif dan } \\
\text { signifikan }\end{array}$ \\
\hline
\end{tabular}

Sumber : hasil olah SPSS 


\section{PEMBAHASAN}

\section{Pengaruh Profitabilitas Terhadap Struktur Modal}

Hipotesis dalam penelitian ini menyatakan Profitabilitas berpengaruh positif dan signifikan terhadap struktur modal. Profitabilitas diproksikan dengan Return On Equity (ROE), sedangkan struktur modal diproksikan dengan Debt to Equity Ratio (DER). Teori yang mendukung penelitian ini adalah signaling theory. Peningkatan profitabilitas akan ditangkap sebagai sinyal positif yang dapat meningkatkan kepercayaan para pemilik modal untuk menginvestasikan modalnya. Dengan profitabilitas yang tinggi akan memudahkan perusahaan untuk menarik minat para investor untuk berinvestasi. Para investor cenderung melihat kemampuan perusahaan dalam menghasilkan laba. Hasil analisa yang menguji pengaruh ROE terhadap DER menunjukkan hasil bahwa terdapat pengaruh positif dan tidak signifikan yang berarti apabila nilai ROE meningkat maka nilai DER juga akan mengalami peningkatan namun tidak signifikan. Secara empiris dalam penelitian ini bahwa profitabilitas sangat rendah sehingga berpengaruh positif namun tidak signifikan terhadap struktur modal artinya keuntungan perusahaan pembiayaan yang terdaftar di BEI tidak berdampak besar terhadap peningkatan struktur modal perusahaan. Mengingat obyek penelitian adalah perusahaan pembiayaan maka pihak investor dalam melakukan memutuskan investasi juga harus memperhitungkan resiko kredit macet atas usaha pembiayaan yang dilakukan oleh perusahaan tersebut.

\section{Pengaruh Struktur Modal Terhadap Nilai Perusahaan}

Pengujian Hipotesis dalam penelitian ini yaitu struktur modal berpengaruh positif dan signifikan terhadap nilai perusahaan. Struktur modal diproksikan dengan Debt to Equity Ratio (DER) dan nilai perusahaan diproksikan dengan Price Book Value (PBV). Teori yang mendukung hasil penelitian ini adalah teori trade-off yang menjelaskan bahwa penggunaan utang dapat mengurangi beban pajak dan biaya agensi perusahaan (Brigham \& Houston, 2006). Penggunaan utang dalam mengurangi beban pajak akan berdampak pada peningkatan nilai perusahaan. Namun apabila hutang sudah mencapai batas maksimal maka akan mengalami penurunan karena penghematan pajak tidak mampu menanggung resiko yang ada. Teori lainnya yaitu signalling theory dimana perusahaan yang meningkatkan utang merupakan tanda bahwa perusahaan tersebut yakin dengan prospek perusahaan dimasa mendatang, sehingga penambahan utang akan memberikan sinyal positif bagi para investor.

Hasil pengujian Debt to Equity Ratio (DER) terhadap Price Book to Value (PBV) menunjukkan terdapat pengaruh positif dan tidak signifikan, yang berarti bahwa setiap terjadi peningkatan DER maka akan diikuti dengan peningkatan nilai perusahaan pada perusahaan pembiayaan yang terdaftar di BEI. Namun perubahan DER tidak berpengaruh besar terhadap nilai perusahaan. Apabila dilihat pada hasil analisa deskriptif pada nilai rata-rata DER yang cukup tinggi selama periode pengamatan bila dibandingkan nilai perusahaan maka hal ini mengindikasikan bahwa perusahaan pembiayaan yang terdaftar di BEI melebihi batas struktur modal optimal sehingga setiap pertambahan hutang justru akan menurunkan nilai perusahaan.

\section{Pengaruh Profitabilitas Terhadap Nilai Perusahaan}

Hipotesis dalam penelitian ini yaitu struktur modal berpengaruh positif dan signifikan terhadap nilai perusahaan. Struktur modal diproksikan dengan Debt to Equity Ratio (DER) dan nilai perusahaan diproksikan dengan Price Book Value (PBV). Hasil uji ROE terhadap PBV menunjukkan adanya pengaruh positif dan signifikan terhadap PBV. Hal ini berarti bahwa apabila ROE meningkat maka nilai perusahaan ikut meningkat begitu pula sebaliknya apabila terjadi penurunan pada ROE maka PBV sebagai proksi

dari nilai perusahaan juga menurun. Semakin tinggi profit yang dicapai merupakan 
indikasi prospek perusahaan pembiayaan yang terdaftar di BEI makin baik sehingga dapat menarik minat para investor untuk berinvestasi dengan membeli saham perusahaan. Permintaan saham yang meningkat akan meningkatkan nilai perusahaan. Peningkatan nilai perusahaan sebagai akibat dari peningkatan kepercayaan para investor karena sinyal positif yang diterima karena adanya peningkatan profit yang terjadi pada perusahaan pembiayaan yang terdaftar di BEI.

Hasil penelitian ini sesuai dengan signalling theory menurut (Bringham \& Houston, 2013) merupakan suatu perilaku manajemen perusahaan dalam memberi petunjuk untuk investor terkait pandangan manajemen pada prospek perusahaan untuk masa mendatang. Sinyal positif ini akan ditangkap oleh para investor sebagai prospek yang menjanjikan bagi mereka untuk berinvestasi. Peningkatan ROE akan menyebabkan peningkatan permintaan saham oleh investor, sehingga nilai perusahaan pembiayaan yang terdaftar di BEI akan meningkat.

\section{Pengaruh Profitabilitas Terhadap Nilai Perusahaan Dengan Struktur Modal Sebagai Variabel Intervening}

Hipotesis dalam penelitian ini yaitu struktur modal mampu memediasi profitabilitas terhadap nilai perusahaan. Besarnya pengaruh tidak langsung variabel ROE terhadap PBV dengan mediasi DER diperoleh melalui hasil perkalian koefisien jalur (beta) antara pengaruh langsung ROE terhadap DER dengan pengaruh langsung DER terhadap PBV pada perusahaan pembiayaan yang terdaftar di BEI. Pengaruh langsung antara struktur modal ke nilai perusahaan lebih besar dibandingkan dengan pengaruh tidak langsung yaitu profitabilitas ke nilai perusahaan melalui struktur modal. Begitu pula apabila dilihat dari hasil uji $\mathrm{t}$ diperoleh hasil yang tidak signifikan yang berarti struktur modal tidak dapat memediasi. Dari hasil analisis dapat dinyatakan bahwa profitabilitas dapat meningkatkan struktur modal dalam jumlah yang tidak signifikan dan tidak mampu memberikan kontribusi yang besar terhadap nilai perusahaan karena struktur modal tidak mampu memediasi pengaruh profitabilitas terhadap nilai perusahaan. Dalam menjalankan usahanya perusahaan pembiayaan selain menjaga tingkat likuiditas perusahaan, masalah ekonomi makro dan masalah kredit macet yang dialami perusahaan pembiayaan tidak lepas dari masalah utang yang dapat mempengaruhi profitabilitas perusahaan.

\section{KESIMPULAN DAN SARAN}

\section{KESIMPULAN}

Berdasarkan data penelitian dan hasil pengujian yang telah dilakukan, maka dapat ditarik beberapa kesimpulan bahwa :

1. Profitabilitas berpengaruh positif dan tidak signifikan terhadap struktur modal, yang artinya semakin tinggi profitabilitas maka semakin tinggi pula nilai struktur modal namun dampak kenaikannya tidak berdampak besar. Hal ini mengindikasikan bahwa melalui pencapaian profitabilitas memberi sinyal positif bagi para investor untuk menginvestasikan modalnya pada perusahaan pembiayaan yang terdaftar BEI. Profitabilitas mampu memberikan keyakinan pada perusahaan pembiayaan dalam mencari sumber dana dari para investor melalui penjualan saham.

2. Struktur modal berpengaruh positif dan tidak signifikan terhadap nilai perusahaan, artinya semakin tinggi struktur modal maka semakin tinggi pula nilai perusahaan namun dampak

kenaikannya tidak besar. Kenaikan struktur modal yang tidak signifikan ini timbul karena struktur modal perusahaan sudah mencapai titik optimal sehingga setiap 
peningkatan jumlah hutang justru akan menurunkan nilai perusahaan. Apabila hutang sudah mencapai batas maksimal maka akan mengalami penurunan karena penghematan pajak tidak mampu menanggung resiko yang ada.

3. Profitabilitas berpengaruh positif dan signifikan terhadap nilai perusahaan, yang artinya semakin tinggi profitabilitas maka semakin tinggi pula nilai perusahaan pembiayaan yang terdaftar di BEI. Nilai profit yang tinggi memberikan sinyal atas prospek keberhasilan perusahaan di masa mendatang sehingga berdampak pada peningkatan harga saham. Peningkatan harga saham akan menarik minat para investor dalam menanamkan modalnya dengan membeli saham perusahaan. Permintaan saham yang meningkat berdampak pada peningkatan nilai perusahaan. Keuntungan mampu menarik minat para investor untuk menanamkan modalnya.

4. Profitabilitas dapat meningkatkan struktur modal dalam jumlah yang tidak signifikan dan struktur modal tidak mampu memberikan kontribusi yang besar terhadap nilai perusahaan karena struktur modal tidak mampu memediasi pengaruh profitabilitas terhadap nilai perusahaan. Melihat dari hasil perhitungan pengaruh langsung dan tidak langsung didapatkan hasil bahwa nilai pengaruh langsung jauh lebih besar dibanding pengaruh tidak langsung. Struktur modal tidak mampu memediasi hubungan antara profitabilitas terhadap nilai perusahaan. Profitabilitas merupakan salah satu faktor yang mempengaruhi nilai perusahaan

\section{SARAN}

1. Bagi manajer perusahaan, diharapkan melalui penelitian ini mampu memberikan sinyal kepada investor bahwa dengan meningkatnya profitabilitas akan berdampak pada meningkatnya harga saham.

2. Bagi investor, diharapkan melalui penelitian ini dapat membantu investor dalam pengambilan keputusan berinvestasi dalam mempertimbangkan profitabilitas sebagai indikator penilaian potensi perusahaan.

3. Bagi peneliti selanjutnya dapat menjadi rujukan saat melakukan penelitian untuk memilih variabel intervening lainnya yang sekiranya mampu memediasi terhadap nilai perusahaan

\section{REFRENSI}

Ananda, N. A., \& Putra, N. N. (2016). Pengaruh Growth Opportunity Terhadap Nilai Perusahaan Melalui Struktur Modal pada Perusahaan Sektor Property, Real Estate \& Building Construction yang. Jurnal Ilmu Manajemen Ekonomi Bisnis , 15-28.

Brigham, \& Houston. (2006). Fundamental Of Financial Management: Dasar-dasar Manajemen Keuangan (Vol. Ketiga). Salemba Empat: Jakarta.

Bringham, \& Houston. (2013). Dasar-dasar Manajemen Keuangan (11 ed., Vol. 1). Jakarta: Salemba Empat.

Citra, K. A., Paramita, P., Parta, \& Sedana, I. B. (2018). Peran Struktur Modal dalam Memediasi Pengaruh Pertumbuhan Perusahaan Terhadap Nilai Perusahaan Pada Perusahaan Properti Di BEI. E-Jurnal Manajemen Unud, 7.

Fakhruddin, \& Hadianto. (2001). Perangkat Dan Model Analisis Investasi di Pasar Modal. Jakarta: Elex Media Komputindo.

Ghozali, I. (2016). Aplikasi Analisis Multivariete Dengan Program IMB SPSS 23 (Vol. 
Edisi 8). Semarang: Badan Penerbit Universitas Diponegoro.

Gultom, R.,\&Wijaya,A.S. (2013). Analisa Faktor-faktor Yang Mempengaruhi Nilai Perusahaan Pada Perusahaan Farmasi Di Bursa Efek Indonesia. Jurnal Wira Ekonomi Mikroskil .

Hamidy, R. R., \& dkk. (2015). Pengaruh Struktur Modal Terhadap Nilai Perusahaan Dengan Profitabilitas Sebagai Variabel Intervening Pada perusahaan Properti dan Real Estate Di BEI. E-Jurnal Ekonomi dan Bisnis Universitas Udayana, 4-10.

Hermuningsih, S. (2012). Pengaruh Profitabilitas, Size Terhadap Nilai perusahaan Dengan Struktur Modal Sebagai Variabel Intervening. Jurnal Siasat Bisnis , 232 $-242$.

IDX. (2014 sampai 2017). Laporan Keuangan dan Tahunan Perusahaan Tercatat di Bursa Efek Indonesia. Jakarta: Bursa Efek Indonesia.

Mahendra. (2011). Pengaruh Kinerja Keuangan Terhadap Nilai Perusahaan pada Perusahaan Manufaktur di BEI. Jurnal Ilmiah Ekonomi dan Bisnis .

Nurul Azmi, I. \& (2018). Pengaruh Profitabilitas, Ukuran Perusahaan Terhadap Nilai Perusahaan Dengan Struktur Modal Sebagai Intervening Pada Perusahaan Manufaktur Yang Terdaftar di BEI. Jurnal Ilmu Manajemen Bisnis \& Terapan.

Pasaribu, M. Y., \& dkk. (2016). Pengaruh Struktur Modal, Struktur Kepemilikan Dan Profitabilitas Terhadap Nilai Perusahaan Pada Perusahaan Sektor Industri Dasar Dan Kimia Yang Terdaftar Di BEI. Jurnal Administrasi Bisnis, 35, 23-32.

Priyatno, D. (2010). Paham Analisa Statistik Data dengan SPSS. Yogyakarta: Mediakom.

Rahayu, M., \& Sari, B. (2016). Faktor-faktor yang Mempengaruhi Nilai Perusahaan. JOM FISIP , 3, 2.

Sugiarto. (2009). Struktur Modal, Struktur Kepemilikan Perusahaan, Permasalahan

Keagenan \& Informasi Asimetri. Yogyakarta: Graha Il 